\title{
Canine distemper virus detection by different methods of One-Step RT-qPCR
}

\author{
Detecção do vírus da cinomose canina por diferentes métodos de One-Step RT-qPCR
}

\author{
Claudia de Camargo Tozato ${ }^{I}$ Vívian Ferreira Zadra \\ Caroline Rodrigues Basso ${ }^{\mathrm{II}}$ João Pessoa Araújo Junior ${ }^{\mathrm{I}, \mathrm{III}}$
}

\section{ABSTRACT}

Three commercial kits of One-Step RT-qPCR were evaluated for the molecular diagnosis of Canine Distemper Virus. Using the kit that showed better performance, two systems of Realtime RT-PCR (RT-qPCR) assays were tested and compared for analytical sensitivity to Canine Distemper Virus RNA detection: a One-Step RT-qPCR (system A) and a One-Step RT-qPCR combined with NESTED-qPCR (system B). Limits of detection for both systems were determined using a serial dilution of Canine Distemper Virus synthetic RNA or a positive urine sample. In addition, the same urine sample was tested using samples with prior centrifugation or ultracentrifugation. Commercial kits of One-Step RT-qPCR assays detected canine distemper virus RNA in 10 (100\%) urine samples from symptomatic animals tested. The One-Step RT-qPCR kit that showed better results was used to evaluate the analytical sensitivity of the $A$ and $B$ systems. Limit of detection using synthetic RNA for the system $A$ was 11 RNA copies $\mu L^{-1}$ and 110 $R N A$ copies $\mu l^{-1}$ for first round System B. The second round of the NESTED-qPCR for System B had a limit of detection of 11 copies $\mu l^{-1}$. Relationship between $C t$ values and RNA concentration was linear. The RNA extracted from the urine dilutions was detected in dilutions of $10^{-3}$ and $10^{-2}$ by System $A$ and $B$ respectively. Urine centrifugation increased the analytical sensitivity of the test and proved to be useful for routine diagnostics. The One-Step RTqPCR is a fast, sensitive and specific method for canine distemper routine diagnosis and research projects that require sensitive and quantitative methodology.

Key words: canine distemper, molecular diagnosis, One-Step RTqPCR, urine, centrifugation.

RESUMO

Três kits comerciais de One-Step RT-qPCR foram avaliados para o diagnóstico molecular do Virus da Cinomose Canina.Utilizando o kit que apresentou melhor desempenho, dois sistemas de RT-PCR em tempo real (RT-qPCR) foram comparados quanto à sensibilidade analítica na detecção do RNA do Vírus da Cinomose Canina:One-Step RT-qPCR (Sistema A) e One-Step RT-qPCR seguido da NESTED-qPCR (Sistema B).Os limites de detecção dos dois sistemas foram determinados utilizando diluição seriada de RNA sintético do Virus da Cinomose Canina ou de uma amostra de urina positiva. Adicionalmente, uma amostra de urina foi avaliada com centrifugação ou ultracentrifugação prévia. Os kits comerciais de One-Step RT-qPCR amplificaram o RNA do virus da cinomose canina em $10(100 \%)$ amostras de urinas de animais sintomáticos. O kit de One-Step RT-qPCR que apresentou melhor resultado foi utilizado para avaliar a sensibilidade analítica dos sistemas $A$ e $B$. Na reação da curva padrão com $R N A$ sintético, o limite de detecção do sistema A foi de 11 cópias de $R N A \mu L^{-1}$. No sistema $B$ foi de 110 cópias de RNA $\mu L^{-1}$ na One-Step RT-qPCR e 11 cópias de $R N A \mu L^{-1}$ na NESTED-qPCR. A relação entre os valores de Ct e concentração de RNA foi linear. $O$ RNA extraído das diluições da urina foi detectado nas diluições de $10^{-3}$ e10-2 pelos sistemas A e B, respectivamente. A centrifugação prévia da urina aumentou a sensibilidade analitica da análise e mostrou ser importante para a rotina diagnóstica. A reação de One-Step RT$P C R$ é um método rápido, sensivel, específico e aplicável na rotina de diagnóstico molecular da cinomose e em projeto de pesquisa que requer metodologia quantitativa e sensivel.

Palavras-chave: cinomose canina, diagnóstico molecular, OneStep RT-qPCR, urina, centrifugação.

\section{INTRODUCTION}

Canine Distemper (CD) is a severe and often lethal infectious disease that affects dogs and a broad range of terrestrial and aquatic animals (CARVALHO et al., 2012). The disease is caused by

${ }^{\mathrm{I}}$ Departamento de Microbiologia e Imunologia, Instituto de Biociências, Universidade Estadual Paulista Júlio de Mesquita Filho (UNESP), 18618-000, Botucatu, SP, Brasil. E-mail: jpessoa@ibb.unesp.br. .Corresponding author.

IIDepartamento de Química e Bioquímica, Instituto de Biociências, Universidade Estadual Paulista Júlio de Mesquita Filho (UNESP), Botucatu, SP, Brasil.

IIIInstituto de Biotecnologia (IBTEC), Universidade Estadual Paulista Júlio de Mesquita Filho (UNESP), Botucatu, SP, Brasil. 
Canine Distemper Virus (CDV), a Morbillivirus of the Paramyxoviridae family (ICTV, 2014). CDV is an enveloped and pleomorphic virion with a helical capsid that is associated with a single, non-segmented RNA genome of negative polarity. Direct contact with nasal, oral secretions or urine of infected animals is the major route of CDV transmission. Recently, outbreaks of distemper have been identified in dogs and an increasing number of host species, which has been the subject of many studies to elucidate the potential mutations and viral mechanisms that may be involved in host susceptibility (ZHAO et al., 2010; MEGID et al., 2013; DI SABATINO et al., 2014). Clinical signs of canine distemper consist of respiratory and/ or gastrointestinal symptoms that may or may not be associated with neurological symptoms (CARVALHO et al., 2012).

Diagnosis of canine distemper is often based on clinical suspicion. However, due to disease without typical findings of distemper, the similarity of clinical signs with other ailments and high spread of disease, the laboratory diagnosis is crucial. In the past decade, several gel-based molecular assays were developed for CDV detection (FRISK et al. 1999; HEADLEY et al., 2009; ROSA et al., 2012). However, to increase efficiency detection of CDV in samples with low viral load the NESTED RT-PCR has been shown to be the most sensitive method of CDV diagnoses (KIM et al., 2001; DI FRANCESCO et al., 2012).

RT-qPCR assays have been applied to detect and quantify canine distemper virus in clinical specimens of naturally infected dogs or to distinguish vaccine strains from wild strains, using two-step and real-time probes chemistry (ELIA et al., 2006; SCAGLIARINI et al., 2007; FISCHER et al., 2013; WILKES et al., 2014). Recently, surface plasmon resonance (SPR), electrochemical impedance spectroscopy (EIS) and conjugated gold nanoparticles methodologies were also developed for CDV detection (BASSO et al., 2013; 2015a; 2015b).

There is a wide range of commercials reagents and kits for RT-qPCR that use different chemistry amplification. The RT-qPCR yields depend on protocols standardisation, reagents, gene target, primers, template preparation and analytical method used. Various samples types, such as blood, conjunctival swabs and urine, have been used for CDV diagnosis. Urine is useful in the ante mortem diagnosis of distemper, easier to collect than other body fluids and shows great sensitivity in different clinical presentations of canine distemper (GEBARA et al., 2004; ELIA et al., 2006). The aim of this study was to evaluate three commercial kits of One-Step RT-qPCR and to compare the analytical sensitivity of One-Step RT-qPCR (System A) and One-Step RT-qPCR combined with NESTED-qPCR (System B) to detect CDV RNA in urine samples from dogs with clinical suspicion of CDV infection.

\section{METHODS}

Twenty urine samples from dogs were tested to compare the ability of CDV RNA detection of three commercial kits of One-Step RT-qPCR. Urine samples from dogs with clinical suspicion of CDV such as conjunctivitis, bronchitis, catarrhal pneumonia, gastroenteritis or neurological disturbances and 10 urines samples from healthy dogs without sign of CD were collected. RNA was harvested from one hundred microliters of urine using the Total RNA Purification $\mathrm{Kit}^{\mathrm{a}}$ according to the manufacturer's instructions and stored at $-80^{\circ} \mathrm{C}$ until further use.

One-Step RT-qPCR was performed using three commercial kits designated as I, II and III, according to each manufacturer's instructions. Two microliters of RNA extracted was used in a final volume reaction of $20 \mu \mathrm{L}$. The primer pair used in the three One-Step RT-qPCR kits was CDV-For (5'-AGC TAG TTT CAT CTT AAC TAT CAA ATT-3') and CDV-Rev (5'-TTA ACT CTC CAG AAA ACT CAT GC-3') which produced an amplicon of 83 bp (905931 and 966-987 nucleotide nucleoprotein positions, respectively), designed by ELIA et al., (2006), in final concentration of $300 \mathrm{nM}$. A negative control was performed using nuclease-free water.

The reactions prepared with Kit I contained 1XRT-PCR Mix, $0.2 \mu \mathrm{L}$ of RT Mix for One-Step RT-qPCR, primers and nuclease free water. Cycling conditions were: reverse transcription at $50^{\circ} \mathrm{C}$ for $10 \mathrm{~min}, \mathrm{PCR}$ initial activation step at $95^{\circ} \mathrm{C}$ for $5 \mathrm{~min}, 40$ cycling of denaturation at $95^{\circ}$ for $30 \mathrm{~s}$ and annealing/extension $60^{\circ} \mathrm{C}$ for $30 \mathrm{~s}$, followed by dissociation curve.

The reactions prepared with Kit II contained 1X RT-PCR Mix, 20U of RT Mix for One-Step RTqPCR, $0.2 \mu \mathrm{L}$ of Reference Dye for Quantitative $\mathrm{PCR}$, primers and ultrapure water.Cycling conditions were: reverse transcription at $44^{\circ} \mathrm{C}$ for $45 \mathrm{~min}$, PCR initial activation step at $94^{\circ} \mathrm{C}$ for $2 \mathrm{~min}, 40$ cycling of denaturation at $94^{\circ}$ for $15 \mathrm{~s}$ and annealing / extension $60^{\circ} \mathrm{C}$ for $1 \mathrm{~min}$, followed by dissociation curve.

The Kit III reactions were performed using 1X RT-PCR Mix, 1X RT Mix for One-Step RTqPCR, $0.27 \mu \mathrm{M}$ of Reference Dye for Quantitative 
PCR, primers and ultrapure water. Cycling conditions were: reverse transcription at $37^{\circ} \mathrm{C}$ for $15 \mathrm{~min}$, PCR initial denaturation at $95^{\circ} \mathrm{C}$ for $10 \mathrm{~min}, 40$ cycling of denaturation at $95^{\circ}$ for $15 \mathrm{~s}$, annealing at $60^{\circ} \mathrm{C}$ for $30 \mathrm{~s}$ and extensionat $72^{\circ} \mathrm{C}$ for $30 \mathrm{~s}$, followed by dissociation curve.

The One-Step RT-qPCR (System A) and One-Step RT-qPCR combined with NESTEDqPCR (System B) were compared using the RTqPCR Kit I, which showed better dissociation curves, reaction time and $\mathrm{CT}$ averages than other tested kits. The One-Step RT-qPCR of System A was performed using the primer pair CDV-For and CDV-Rev with a primer final concentration of 300nM. The One-Step RT-qPCR of System B was performed using the primer pair $\mathrm{P}-1$ sense (5'-ACAGGATTGCTGAGGACCTAT-3') and P-2 antisense (5'-CAAGATAACCATGTACGGTGC-3') (769-789 and 1055-1035 nucleotide nucleoprotein position of sense and antisense primers, respectively) described by FRISK et al. (1999), which produced an amplicon of $287 \mathrm{bp}$. Negative reactions were applied to the NESTED-qPCR reaction carried out with the CDV-for and CDV- rev primer pair, stated in the System A, using the GoTaq ${ }^{\circledR}$ Green Master $\mathrm{Mix}^{\mathrm{b}}$ according to manufacturer's recommendations. Primer concentrations used were $300 \mathrm{nM}$ and $200 \mathrm{nM}$ in the One-Step RT-qPCR and NESTED-qPCR, respectively. Reactions were performed on a 7300 Real Time PCR System ${ }^{c}$ in a final volume of $20 \mu \mathrm{L}$. Negative controls were carried out with urine RNA extracted from a healthy dog without clinical of distemper and nuclease-free water.

The synthetic RNA was provided to access the efficiency and analytical sensitivity of the two RT-qPCR systems. One fragment of $287 \mathrm{bp}$ generated by RT-qPCR was cloned into the pGEM-T easy vector $^{\mathrm{b}}$ and transformed into Escherichia coli DH$5 \alpha$. The recombinant plasmid was quantified using a NanoDrop ${ }^{\circledR}$ ND-1000 Spectrophotometer. The CDVplasmid was treated with restriction enzymes $\mathrm{NaeI}$ and $\mathrm{Ndel}^{\mathrm{d}}$ and separated via electrophoresis on a $1 \%$ agarose gel. Fragment of $692 \mathrm{bp}$ of CDV containing binding sites of the $\mathrm{T} 7$ polymerase was purified using Nucleospin $^{\circledR}$ Gel and PCR Clean Up ${ }^{\mathrm{e}}$ according to the manufacturer's guidelines. The fragment was in vitro transcribed using MEGA shortscript ${ }^{\mathrm{TM}} \mathrm{T} 7^{\mathrm{f}}$ according to the manufacturer's instructions. Product of transcription was treated with DNAse ${ }^{g}$ to eliminate residual DNA and has been tested using RT-qPCR without the reverse transcriptase to assess RNA purity.

The transcribed RNA was quantified using Qubit $^{\circledR}$ 2.0 Fluorometer ${ }^{\mathrm{h}}$ and the copies number was estimated. The quantified RNA was diluted in sample matrix in 10-fold serial dilutions and was subjected to System A and B in duplicate. Standard curve of both systems was constructed from serial 10-fold dilutions $\left(1.1 \times 10^{5}\right.$ to $1.1 \times 10^{0}$ RNA copies per $\left.\mu \mathrm{l}\right)$ of synthetic RNA using the Applied Biosystems 7000 System SDS software.

One RT-qPCR positive urine sample was diluted to $10^{-5}$ in RT-qPCR negative urine and, after RNA extraction, tested in duplicate using the RTqPCR Systems A and B.

Additionally, to verify the amount of RNA in the urine sample under centrifugation, $1 \mathrm{ml}$ of sample was centrifuged at $8,000 \times \mathrm{g}$ for 8 minutes and $1 \mathrm{ml}$ was ultracentrifuged at $100,000 \times \mathrm{g}$ for 2 hours. One hundred microliters of the pelleted samples were used for RNA extraction and subjected to the two RTqPCR systems.

\section{RESULTS AND DISCUSSION}

All ten RNA samples extracted from urine samples of dogs with clinical suspicion of CDV (100\%) were positive with the three kits used. Ten RNA samples extracted from urines samples of healthy dogs and the negative control did not show amplification or peaks in the melting curve analysis. The RT-qPCR duration and average CT values were $2: 00 \mathrm{~h} / 27.8,3: 20 \mathrm{~h} / 24.3$ and $2: 45 \mathrm{~h} / 29.3$ for the Kit I, II and III, respectively. Melting temperature peaks varied from $73.8^{\circ} \mathrm{C}$ to $74.5^{\circ} \mathrm{C}, 74.6^{\circ} \mathrm{C}$ to $75.8^{\circ} \mathrm{C}$ and $74.2^{\circ} \mathrm{C}$ to $75.7^{\circ} \mathrm{C}$ for the Kit I, II and III, respectively. Kit II resulted in the lowest average CT values; however, in melting curve analysis of positive samples, there was a broad base, nonspecific peaks and melting temperature variation of $1.2^{\circ} \mathrm{C}$. Kit I and III analyses showed melting temperature variations of $0.7^{\circ} \mathrm{C}$ and $1.5^{\circ} \mathrm{C}$, respectively, but non-specific peaks were not observed.

Three commercial kits were able to detect CDV RNA in urine samples. Over the past several years, real-time PCR has become the leading tool for the detection and quantification of nucleic acids. Increase of commercial master mix kits enabled diagnostic laboratories to implement real-time PCR. It has been demonstrated that the reverse transcription reaction mainly depends on the initial molecular step (the reverse transcription), choice of master mix reagents, quality of enzymes, concentration of reaction mix components, such as primers, probes and methodology used that can impact the sensitivity of results for real-time PCR assays (SERGERIE et al., 2007; BUZARD et al., 
2012; PICARD-MEYER, 2015). In this study, the Kit I was faster, with better melting curves showing better performance and was used to evaluate the analytical sensitivity of Systems A and B.

The standard curve of One-Step RTqPCR Systems A and B was generated and showed linearity over the entire quantification range. System A showed a slope of -3.5 , a coefficient of linear regression $\left(\mathrm{R}^{2}\right)$ of 0.99 and an efficiency of $93.0 \%$. System B showed a slope of -3.65 , a linear regression $\left(R^{2}\right) 0.99$ and an efficiency of $87.0 \%$. System A was able to detect synthetic CDV RNA down to $1.1 \mathrm{x} 10$ RNA copies $\mu \mathrm{L}^{-1}$. System B amplified the synthetic RNA down to $1.1 \times 10^{2}$ copies $\mu \mathrm{L}^{-1}$ in the RT-qPCR and $1.1 \times 10$ RNA copies $\mu \mathrm{L}^{-1}$ in the NESTED-qPCR. System A detected CDV RNA in diluted urine down to $10^{-3}$ and System B detected CDV RNA in diluted urine down to $10^{-2}$ (Table 1).

The NESTED reaction usually increases the analytical sensitivity of conventional PCR reactions for CDV detection and is often applied for diagnostic purposes. When using conventional reaction, the limit of detection of $\mathrm{N}$ gene of CDV was increased hundred fold using the One-Step RT-PCR combined with the NESTED PCR (KIM et al., 2001). The CDV was detected in $50.0 \%$ of urine samples from symptomatic dogs by One-Step RT-PCR and in $75.0 \%$ of urine samples when combined with NESTED-PCR (SHIN et al., 2004). Thus, in the present study, the System A showed superior analytical sensitivity compared to System B due to greater reaction efficiency. The qPCR is more sensitive, faster and reduces the risk of broad contamination. Composition of reagents, gene target and primers pair plays a role in the reaction yield. The reaction with the primer pair CDV-for and CDV-rev (System A) showed improved efficiency and sensitivity compared to the P-1 and P-2 primer pair (System B), probably due to the primer used. Particularly in studies of diagnostic methods that perform the NESTED-PCR, there is a high risk of broad laboratory contamination. Overall, qPCR is performed only from negative samples, previously detected in melting curve analyses, without opening positive tubes, reducing the risk of cross contamination and making this method a useful option for studies that require this tool.

The System A detected RNA down to $1.1 \mathrm{x}$ 10 RNA copies $\mu \mathrm{L}^{-1}$ and was more sensitive than twostep probe based chemistry using the same primer pair (ELIA et al., 2006). Benefits of SYBR Green I OneStep RT-qPCR assays over conventional RT-PCR and two-step qPCR detection methods, particularly for diagnosis, include their large dynamic range, ability to be scaled up for high through put applications and superior analytical sensitivity and specificity due to the curve dissociation (DUPOUEY et al., 2014). These assays are also faster, more practical in considering all of the required reagents in the RNA transcription reaction, optimise laboratory time and present a good cost to benefit ratio (SCHMITTGEN et al., 2000).

$\mathrm{CDV}$ is one of the most important infectious agents within canine population and has worldwide distribution and frequently affects unvaccinated young dogs (LAMB; KOLAKOFSKY, 2001). However, distemper has been known to occur in vaccinated dogs and outbreaks in various other hosts naturally infected, such as non-human primates have been investigated (BEINEKE et al., 2009; SAKAI et al., 2013). The definitive diagnosis of distemper often requires the laboratory tests to confirm disease without the typical symptoms and the similarity of clinical signs with other ailments. System A showed to be a sensitive and practical method that can be applied to detect CDV and can be used for target quantification in academic laboratory applications.

The urine centrifuged at $8,000 \times \mathrm{g}$ for 8 minutes showed increases in RNA copy number

Table 1 - Comparison of absolute viral quantification of urine dilution samples, centrifuged urine and ultracentrifuged urine in system A and $\mathrm{B}$.

\begin{tabular}{lcc}
\hline Sample & System A $\left(\operatorname{copies} \mu \mathrm{L}^{-1}\right)$ & System B $\left(\mathrm{copies} \mu \mathrm{L}^{-1}\right)$ \\
\hline Urine $10^{0}$ & $2.8 \times 10^{5}$ & $7.1 \times 10^{4}$ \\
Urine $10^{-1}$ & $4.0 \times 10^{3}$ & $1.1 \times 10^{3}$ \\
Urine $10^{-2}$ & 622.6 & $129.39^{4}$ \\
Urine $10^{-3}$ & 29.3 & - \\
Urine $10^{-4}$ & - & - \\
Urine $10^{-5}$ & - & - \\
Centrifuged Urine & $9.0 \times 10^{5}$ & $1.7 \times 10^{5}$ \\
Ultracentrifuged Urine & $9.7 \times 10^{5}$ & $2.4 \times 10^{5}$ \\
\hline
\end{tabular}


detection, which was approximately 3.2 and 2.3 times in System A and B, respectively. Nucleoprotein gene is considered the most conserved gene of the Morbillivirus family and the most expressed gene due to the transcriptional organization. As a result, this gene has been commonly used for CDV diagnosis. Urine is currently the best sample for CDV ante-mortem diagnosis and has been usefully applied. CDV causes cystitis and inclusion bodies, which can be found clearly in the cytoplasm or less frequently in the nucleus of urinary bladder cells by histology. Most likely, the RNA virus is detected in the urine due to infected urinary epithelial cell flaking and the presence of free virus in the urine. Detection of CDV RNA extracted from samples centrifuged at $8,000 \times g$ for 8 minutes revealed a higher quantity of virus RNA (approximately three fold), most likely due to infected cell sedimentation containing the intracytoplasmic viral RNA. Ultracentrifugation results in concentrated viral particles, which increase sensitivity slightly when compared to centrifugation. Urine centrifugation at $8,000 \times g$ for 8 minutes prior to RNA extraction is easy to perform, increases diagnostic sensitivity and is an important tool, particularly in samples with low viral load.

\section{CONCLUSION}

In conclusion, the three kits of One-Step RT-qPCR were able to detect CDV in urine samples. The Kit I was faster, with better melting curves indicating better performance. The paper describes a One-Step RT-qPCR and a One-Step RT-qPCR combined with NESTED-qPCR (System A and B, respectively) with the primer pair CDV-for and CDVrev showing better analytical sensitivity. One-Step RT-qPCR is a sensitive and rapid method, which will support routine canine distemper laboratory surveillance and facilitate research projects that require sensitive and quantitative CDV detection. In addition, centrifugation of urine samples prior to RNA extraction appears to increase the test sensitivity.

\section{SOURCES AND MANUFACTURES}

a- Norgen Biotek Corporation, Thorold, ON, Canada.

b- Promega, Madison, WI, USA.

c- Applied Biosystems, Life Technologies Corp., Carlsbad, CA, USA.

d- Fermentas/Thermo Scientific, Burlington, Canada.

e- Macherey-Nagel, Düren, Germany.

f- Invitrogen, Life Technologies Corp., Carlsbad, CA, USA.

g- Sigma Sigma-Aldrich, St Louis, MO, USA.

h- Life Technologies Corporation, Carlsbad.
DECLARATION

OF

CONFLICTING INTERESTS

The authors of the manuscript disclose that there is no conflict of interest and that there were no commercial relationships with the manufacturers of any products used in this article.

\section{ACKNOWLEDGEMENTS}

Financial support for the research was provided by the Fundação de Amparo à Pesquisa do Estado de São Paulo (FAPESP-11/50889-9).

\section{REFERENCES}

BASSO, C.R. et al. A immunosensor for the diagnosis of canine distemper virus infection using SPR and EIS. Analytical Methods, v.5, p.5089-5095, 2013. Available from: <http://pubs.rsc.org/en/ content/articlepdf/2013/ay/c3ay41087k>. Accessed: Apr. 08, 2014. doi: $10.1039 / \mathrm{c} 3 \mathrm{ay} 41087 \mathrm{k}$.

BASSO, C.R. et al. Effects of protein a in detection of canine distemper virus through immunosensor construction. IEEE Sensors Journal, v.15, n.8, p.4677-4683, 2015a. Available from: <http:// ieeexplore.ieee.org/stamp/stamp.jsp?tp=\&arnumber=7094228>. Accessed: Sept. 15, 2015. doi: 10.1109/JSEN.2015.2426421.

BASSO, C.R.et al. A fast and highly sensitive method for the detection of canine distemper virus by the naked eye. Analytical Methods, v.7, n.6, p.2264-2267, 2015b. Available from: <http:// pubs.rsc.org/en/content/articlepdf/2015/ay/c4ay02644f $>$. Accessed: Sept. 15, 2015. doi: 10.1039/C4AY02644F.

BEINEKE, A. et al. Pathogenesis and immunopathology of systemic and nervous canine distemper. Veterinary Immunology and Immunopathology, v.127, n.1-2, p.1-18, 2009.Available from: <http://www.sciencedirect.com/science/article/pii/ S0165242708003668>. Accessed: Apr. 08, 2014. doi: 10.1016/j. vetimm.2008.09.023.

BUZARD, G.S. et al. Multi-platform comparison of ten commercial master mixes for probe-based real-time polymerase chain reaction detection of bioterrorism threat agents for surge preparedness. Forensic Science International, v.223, n.1-3, p.292-297, 2012. Available from: $<$ http://www.sciencedirect.com/science/article/pii/ S0379073812004574>. Accessed: Apr. 08, 2014. doi: 10.1016/j. forsciint.2012.10.003.

CARVALHO, O.V. et al. Immunopathogenic and Neurological Mechanisms of Canine Distemper Virus. Advances in Virology, v.2012, Article ID 163860, 10 pages. Avaliable from: <http:// dx.doi.org/10.1155/2012/163860>. Acessed: Apr. 08, 2014. doi: $10.1155 / 2012 / 163860$

DI FRANCESCO, C.E. et al. Detection by hemi-nested reverse transcription polymerase chain reaction and genetic characterization of wild type strains of canine distemper virus in suspected infected dogs. Journal of Veterinary Diagnostic Investigation, v.24, p.107-115, 2012. Available from: <http:// www.ncbi.nlm.nih.gov/pubmed/22362940>. Accessed: Apr. 08, 2014. doi: $10.1177 / 1040638711425700$.

DI SABATINO, D. et al. Arctic lineage-canine distemper virus as a cause of death in Apennine wolves (Canis lupus) in Italy. PLoS 
One, v.9, n.1, p.1-8, 2014. Available from: <http://journals.plos. org/plosone/article? $\mathrm{id}=10.1371 /$ journal.pone. $0082356>$. Accessed: Jan. 10, 2014. doi: 10.1371/journal.pone.0082356.

DUPOUEY, J. et al. Molecular detection of human rhinoviruses in respiratory samples: a comparison of Taqman probe-SYBR green I and BOXTO based real-time PCR assays. Virology Journal, v.11, n.31, p.11-31, 2014. Available from: < http://www. virologyj.com/content/11/1/31>. Accessed: Jan. 10, 2014. doi: $10.1186 / 1743-422 X-11-31$

ELIA, G. et al. Detection of canine distemper virus in dogs by real-time RT-PCR. Journal of Virological Methods, v.36, n.12, p.171-176, 2006. Available from: <http://www.sciencedirect. com/science/article/pii/S016609340600156X>. Accessed: Apr. 08, 2014. doi: 10.1016/j.jviromet.2006.05.004.

FISCHER, C.D.B. et al. Detection and differentiation of field and vaccine strains of canine distemper virus using reverse transcription followed by nested real time PCR (RT-nqPCR) and RFLP analysis. Journal of Virological Methods, v.194, n.1-2, p.39-45, 2013. Available from: <http://www.ncbi.nlm.nih.gov/ pubmed/23942341>. Accessed: Apr. 08, 2014. doi: 10.1016/j. jviromet.2013.08.002.

FRISK, A.L. et al. Detection of canine distemper virus nucleoprotein RNA by reverse transcription-PCR using serum, whole blood, and cerebrospinal fluid from dogs with distemper. Journal of Clinical Microbiology, v.37, n.11, p.3634-3643, 1999. Available from: $<$ http://www.ncbi.nlm.nih.gov/pubmed/10523566>. Accessed: Apr. 08, 2014. doi: 113634-3643.

GEBARA, C.M.S. et al. Detecção do gene da nucleoproteína do vírus da cinomose canina por RT-PCR em urina de cães com sinais clínicos de cinomose. Arquivo Brasileiro de Medicina Veterinária e Zootecnia, v.56, p.480-487, 2004. Available from: $<$ http://www.scielo.br/scielo.php?script=sci_arttext\&pid=S01020 9352004000400009\&lng=pt\&nrm=iso\&tlng=pt $>$. Accessed: Apr. 08, 2014. doi: 10.1590/S0102-09352004000400009.

HEADLEY, S.A. et al. Molecular detection of canine distemper virus and the immunohistochemical characterization of the neurologic lesions in naturally occurring old dog encephalitis. Journal of Veterinary Diagnostic Investigation, v.21, p.588597, 2009. Available from: <http://vdi.sagepub.com/cgi/pmidlook up?view $=$ long \&pmid $=19737753>$. Accessed: Apr. 08, 2014. doi: $10.1177 / 1040638709021005$.

ICTV(INTERNATIONAL COMITEE ON TAXONOMY OF VIRUS). Virus taxonomy, 2014. Release. Available from: <http:// www.ictvonline.org>. Accessed: Ago. 21, 2015.

KIM, Y.H. et al. Detection of canine distemper virus (CDV) through one step RT-PCR combined with nested PCR. Journal of Veterinary Science, v.2, p.59-63, 2001. Available from: <http:// www.ncbi.nlm.nih.gov/pubmed/14614296>. Accessed: Apr. 08, 2014. doi: 14614296 .

LAMB, R.A.; KOLAKOFSKY, D. Paramyxoviridae: the viruses and their replication. In: FIELDS, B.N. et al. (Eds). Fields virology. 4.ed. Philapdelphia: Lippincott-Raven, 2001. p. $1305-1340$.

MEGID, J. et al. Canine distemper virus infection in a lesser grison (Galictis cuja): first report and virus phylogeny. Pesquisa Veterinária Brasileira, v.33, p.247-250, 2013. Available from:
$<$ http://www.scielo.br/scielo.php?script=sci_arttext\&pid=S0100736X2013000200018>. Accessed: Apr. 08, 2014. doi: 10.1590/ S0100-736X2013000200018.

PICARD-MEYER, E. et al. Cross-platform evaluation of Commercial Real-Time SYBR Green RT-PCR kits for sensitive and rapid detection of European Bat Lyssavirus type 1. BioMed Research International, v.2015, p.18, 2015. Available from: $<$ http://www.ncbi.nlm.nih.gov/pubmed/25785274>. Accessed: Apr. 08, 2014. doi: 10.1155/2015/839518.

ROSA, G.N. et al. Detecção molecular e análise filogenética do gene $\mathrm{H}$ de amostras do vírus da cinomose canina em circulação no município de Campinas, São Paulo. Pesquisa Veterinária Brasileira, v.32, n.1, p.72-77, 2012. Available from: $<$ http://www. scielo.br/scielo.php?pid=S0100-736X2012000100012\&script $=$ sci arttext>. Accessed: Apr. 08, 2014. doi: 10.1590/S0100736X2012000100012.

SAKAI, K. et al. Canine distemper virus associated with a lethal outbreak in monkeys readily adapted to use human receptors. Journal of Virology, v.87, n.12, p.7170-7175, 2013. Available from: <http://www.ncbi.nlm.nih.gov/pubmed/23596291>. Accessed: Apr. 08, 2014. doi: 10.1128/JVI.03479-12.

SCAGLIARINI, A. et al. TaqMan based real time PCR for the quantification of canine distemper virus. Veterinary Research Communication, v.31, n.1, p.261-263, 2007. Available from: <http://link.springer.com/article/10.1007\%2 Fs11259-007-0020-9>. Accessed: Apr. 08, 2014. doi: 10.1128/ JVI.03479-12.

SCHMITTGEN, T.D et al. Quantitative reverse transcriptionpolymerase chain reaction to study mRNA decay: comparison of endpoint and real-time methods. Analytical Biochemistry, v.285, n.2, p.194-200, 2000. Available from: <http://www.sciencedirect. com/science/article/pii/S0003269700947535>. Accessed: Apr. 08, 2014. doi: 10.1006/abio.2000.4753.

SERGERIE, L. et al. Detection limits of several commercial reverse transcriptase enzymes: impact on the low and high abundance transcript levels assessed by quantitative RT-PCR. BMC Molecular Biology, v.8, n.93, p.93, 2007. Available from: $<$ http://www.biomedcentral.com/1471-2199/8/93>. Accessed: Apr. 08, 2014. doi:10.1186/1471-2199-8-93.

SHIN, Y.J. et al. Comparison of one-step RT-PCR and a nested PCR for the detection of canine distemper virus in clinical samples. Australian Veterinary Journal, v.82, p.83-86, 2004. Available from: <http://www.ncbi.nlm.nih.gov/pubmed/15088966>. Accessed: Apr. 08, 2014. doi: 15088966.

WILKES, R.P. et al. Real-time reverse transcription polymerase chain reaction method for detection of canine distemper virus modified live vaccine shedding for differentiation from infection with wild-type strains. Journal of Veterinary Diagnostic Investigation, v.26, n.1, p.27-34, 2014. Available from: <http:// www.ncbi.nlm.nih.gov/pubmed/24532693>. Accessed: Jan. 10, 2014. doi: $10.1177 / 1040638713517232$.

ZHAO, J.J. et al. Phylogenetic analysis of the haemagglutinin gene of canine distemper virus strains detected from breeding foxes, raccoon dogs and minks in China. Veterinary Microbiology, v.140, n.1-2, p.34-42, 2010. Available from: <http://www.ncbi. nlm.nih.gov/pubmed/19647380>. Accessed: Apr. 08, 2014. doi: 10.1016/j.vetmic.2009.07.010. 